\title{
Basic Mechanisms of Arsenic Trioxide (ATO)- Induced Apoptosis in Human Leukemia (HL-60) Cells
}

\author{
Clement Yedjou', Paul Tchounwou ${ }^{1 *}$, John Jenkins², Robert McMurray ${ }^{2}$
}

\begin{abstract}
Background: Acute promyelocytic leukemia (APL) is a blood cancer that affects people of all ages and strikes about 1,500 patients in the United States each year. The standard treatment of APL has been based on the combined administration of all-trans retinoic acid and chemotherapy including anthracyclins and cytarabine. However, $10-20 \%$ of patients relapse, with their disease becoming resistant to conventional treatment. Recently the Food and Drug Administration has approved the use of arsenic trioxide (ATO) or Trisenox for the treatment of APL, based on clinical studies showing a complete remission, especially in relapsed patients. In a recently published study we demonstrated that ATO pharmacology as an anti-cancer drug is associated with its cytotoxic and genotoxic effects in human leukemia cells.
\end{abstract}

Methods: In the present study, we further investigated the apoptotic mechanisms of ATO toxicity using the HL-60 cell line as a test model. Apoptosis was measured by flow cytometry analysis of phosphatidylserine externalization (Annexin $\vee$ assay) and caspase 3 activity, and by DNA laddering assay.

Results: Flow cytometry data showed a strong dose-response relationship between ATO exposure and Annexin-V positive HL-60 cells. Similarly, a statistically significant and dose-dependent increase $(p<0.05)$ was recorded with regard to caspase 3 activity in HL60 cells undergoing late apoptosis. These results were confirmed by data of DNA laddering assay showing a clear evidence of nucleosomal DNA fragmentation in ATO-treated cells.

Conclusion: Taken together, our research demonstrated that ATO represents an apoptosis-inducing agent and its apoptotic mechanisms involve phosphatidylserine externalization, caspase 3 activation and nucleosomal DNA fragmentation.

\section{Introduction}

Arsenic based drugs have been used as effective chemotherapeutic agents to treat several diseases and some tumors [1]. In recent years, arsenic trioxide (ATO) has been found to have a very potent anti leukemic efficacy, especially against acute promyelocytic leukemia (APL). It has been found to produce clinical remission in a high proportion of patients with APL [2]. The Chinese first discovered that a Chinese herb was effective against APL, about 100 years ago. Workers in a university in

\footnotetext{
* Correspondence: paul.b.tchounwou@jsums.edu

${ }^{1}$ Cellomics and Toxicogenomics Research Laboratory, NIH-RCMI Center for Environmental Health, College of Science, Engineering and Technology, Jackson State University, 1400 Lynch Street, Box 18540, Jackson, Mississippi, USA

Full list of author information is available at the end of the article
}

New York City, New York, fractionated this herb, tested the fractions, and found that one fraction was active against APL. When analyzed chemically, this fraction turned out to consist of ATO [2]. The origin of this ATO is believed to be the massive pollution of the rivers in China with arsenic-laden mine tailings, that the Chinese military, who administers the mines in China, discards into the rivers while mining for valuable metals. Medical reports from China have also revealed that ATO induces clinical and hematologic responses in patients with de novo and relapsed APL [2-4]. Several studies have reported that ATO induces apoptosis in malignant cells including APL, non-Hodgkin's lymphoma, multiple myeloma, and chronic lymphocytic leukemia cells [5-7]. In addition, ATO has been found to induce apoptosis in myeloid leukemia cells such as 
U937 and KG-1 [8,9]. Scientific data have demonstrated that ATO induced apoptosis is associated with downregulation of $\mathrm{Bcl}-2$ gene expression, up-regulation of the expression of the proenzymes of caspase 2 and 3 and activation of both caspase 1 and 3 [5,8,9]. ATO induced apoptosis is also associated with the generation of reactive oxygen species that contribute significantly to cell killing [10-12], and inhibition of growth [13]. Previous researches have indicated that the apoptosis-inducing properties of ATO are not restricted to APL, since the viability of different cancer cell lines that originate from the same lymphoid lineage vary when exposed to various concentrations of ATO $[6,14,15]$.

Studies with APL cell lines have shown that ATO treatment activates caspases [16], down-regulates Bcl-2 protein and up-regulates of p53 expression [17]. A recent study from our laboratory has indicated that ATO induces transcription of specific genes that modulate mitogen response, cell cycle progression, programmed cell death, and cellular function in cultured HL-60 promyelocytic leukemia cells. Among these cellular responses of HL-60 cells to ATO are up-regulation of p53 tumor suppressor protein and repression of the $c$-fos transcription factor involved in cell cycle arrest or apoptosis, and modulation of cyclin D1 and cyclin A involved in cell cycle progression [18]. Preclinical studies from our laboratory have also indicated that ascorbic acid (AA), co-administrated with ATO in vitro, enhances ATO activity effect against human leukemia HL-60 cells $[19,20]$, suggesting a possible future role of AA/ATO combination therapy in patients with APL. At pharmacologic doses, ATO inhibits survival and growth of several different human cancer cells in a dose- and time-dependent fashion $[6,21,22]$. Figure 1 shows the

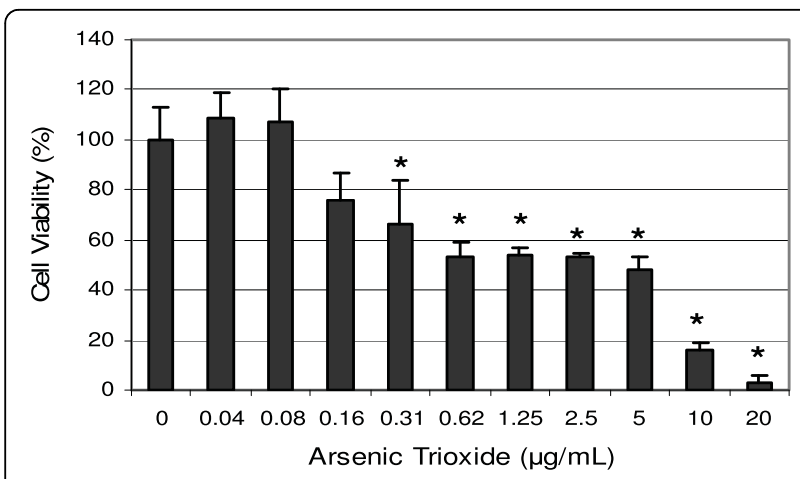

Figure 1 Toxicity of arsenic trioxide to human leukemia (HL-60) cells. HL-60 cells were cultured with different doses of arsenic trioxide for $24 \mathrm{hr}$ as indicated in the Materials and Methods. Cell viability was determined based on the MTT assay. Each point represents a mean \pm SD of 3 experiments with 6 replicates per dose. *Significantly different $(p<0.05)$ from the control, according to the Dunnett's test [22]. in vitro cytotoxic efficacy of ATO on human leukemia (HL-60) cells [22]. However, the specific mechanisms under which ATO exerts its therapeutic effect in cancer cells remain to be elucidated. Therefore, the aim of the present study was to elucidate the apoptotic mechanism of ATO toxicity using HL-60, a promyelocytic leukemia cell line, as a test model.

\section{Materials and methods \\ Chemicals and test media}

Arsenic trioxide (ATO), CASRN 1327-53-3, MW 197.84, with an active ingredient of $100 \%(\mathrm{w} / \mathrm{v})$ arsenic in $10 \%$ nitric acid was purchased from Fisher Scientific (Houston, Texas). Growth medium RMPI 1640 containing $1 \mathrm{mmol} / \mathrm{L}$ L-glutamine was purchased from Gibco BRL products (Grand Island, NY). Fetal bovine serum (FBS), and phosphate buffered saline (PBS) were obtained from Sigma Chemical Company (St. Louis, MO). Annexin V fluorescein isothiocyanale (FITC) kit (contains annexin V FITC, binding buffer and propidium iodide [PI]), and active caspase-3 kit were obtained from BD Biosciences (Pharmingen, Becton Dickinson Co., San Diego, CA, USA).

\section{Cell culture}

The HL-60 promyelocytic leukemia cell line was purchased from American Type Culture Collection -ATCC (Manassas, VA). This cell line has been derived from peripheral blood cells of a 36-year old Caucasian female with acute promyelocytic leukemia (APL). In the laboratory, cells were stored in the liquid nitrogen until use. They were next thawed by gentle agitation of their containers (vials) for $2 \mathrm{~min}$ in a water bath at $37^{\circ} \mathrm{C}$. After thawing, the content of each vial of cells was transferred to a $25 \mathrm{~cm}^{2}$ tissue culture flask, diluted with up to 10 $\mathrm{mL}$ of RPMI 1640 containing $1 \mathrm{mmol} / \mathrm{L} \mathrm{L}$-glutamine (GIBCO/BRL, Gaithersburg, MD) and supplemented with $10 \%(\mathrm{v} / \mathrm{v})$ fetal bovine serum (FBS), $1 \%(\mathrm{w} / \mathrm{v})$ penicillin/streptomycin. The $25 \mathrm{~cm}^{2}$ culture flasks $\left(2 \times 10^{6}\right.$ viable cells) were observed under the microscope, followed by incubation in a humidified $5 \% \mathrm{CO}_{2}$ incubator at $37^{\circ} \mathrm{C}$. Three times a week, they were diluted under same conditions to maintain a density of $5 \times 10^{5}$ cells/ $\mathrm{mL}$, and harvested in the exponential phase of growth. The cell viability was assessed by the trypan blue exclusion test (Life Technologies Corperation, Carlsbad, CA, USA), and manually counted using a hemocytometer.

\section{Annexin V FITC/PI assay by flow cytometry}

Annexin V FITC/PI assay for estimating early cells undergoing apoptosis was performed as described previously [20]. Briefly, $2 \mathrm{~mL}$ of cells $\left(1 \times 10^{6}\right.$ cells $\left./ \mathrm{mL}\right)$ were added to each well of 24 plates and treated with 2 , 4,6 and $8 \mu \mathrm{g} / \mathrm{mL}$ of arsenic trioxide (ATO) for $24 \mathrm{~h}$. Control cells were processed exactly as ATO-treated 
cells, except ATO treatment of these cells was eliminated. These doses were selected based on the results of previous experiments in our laboratory indicating that ATO is highly cytotoxic to HL-60 cells, showing a $24 \mathrm{~h}$ $\mathrm{LD}_{50}$ of $6.4 \pm 0.7 \mu \mathrm{g} / \mathrm{mL}$ [22]. After $24 \mathrm{~h}$ of incubation, $1 \times 10^{6}$ cells $/ \mathrm{mL}$ were counted and washed in PBS, resuspended in binding buffer $(10 \mathrm{mM}$ Hepes $/ \mathrm{NaOH} \mathrm{pH}$ 7.4, $140 \mathrm{mM} \mathrm{NaCl}, 2.5 \mathrm{mM} \mathrm{CaCl} 2)$, and stained with FITC-conjugated annexin V (Pharmingen, Becton Dickinson Co., San Diego, CA, USA). After staining, the cells were incubated for $15 \mathrm{~min}$ in the dark at room temperature. Cells were re-washed with binding buffer and analysed by flow cytometry (FACS Calibar; BectonDickinson) using CellQuest software [23,24].

\section{Active caspase- 3 assay by flow cytometry}

Caspase-3 assays were carried out using a commercially available kit (Phycoerythrin-Conjugated Polyclonal Active Caspase-3 Antibody Apoptosis Kits, Pharmingen). HL-60 cells were grown in RPMI 1640 containing 1 $\mathrm{mmol} / \mathrm{L}$ L-glutamine (GIBCO/BRL, Gaithersburg, MD) and supplemented with $10 \%(\mathrm{v} / \mathrm{v})$ fetal bovine serum (FBS), $1 \%(\mathrm{w} / \mathrm{v})$ penicillin/streptomycin. Two $\mathrm{mL}$ of cells $\left(1 \times 10^{6} \mathrm{cells} / \mathrm{mL}\right)$ were added to each well of 24 wells and treated with $2,4,6$ and $8 \mu \mathrm{g} / \mathrm{mL}$ of arsenic trioxide (ATO) for $24 \mathrm{~h}$. Control cells were processed exactly as ATO-treated cells, except ATO treatment of these cells was eliminated. Control and ATO-treated cells were assayed for caspase-3-like protease according to a previously described protocol [25]. Briefly, $1 \times 10^{6}$ cells $/ \mathrm{mL}$ were washed per concentration with cold PBS (pH 7.4). Washed cells were suspended in Cytofix/Cytoperm solutions and incubated for $20 \mathrm{~min}$ on ice. Cells were pelleted and washed with Perm/Wash buffer. Cells were then centrifuged at $3000 \mathrm{rpm}$ for $5 \mathrm{~min}$ and re-suspended in $0.2 \mathrm{~mL}$ Perm/Wash, $20 \mu \mathrm{L} \mathrm{PE}$ - conjugaled polyclonal rabbit anti-active caspase- 3 antibody and incubated at room temperature for $30 \mathrm{~min}$. Cells were re-suspended in $0.5 \mathrm{~mL}$ of perm/wash buffer and analysis by a flow cytometer (FACS Calibar; Becton-Dickinson) using CellQuest software.

\section{DNA fragmentation analysis by agarose gel electrophoresis}

DNA fragmentation analysis was conducted to confirm the apoptotic mechanism of arsenic trioxide (ATO). Briefly, $2 \mathrm{~mL}$ of cells $\left(1 \times 10^{6} \mathrm{cells} / \mathrm{mL}\right)$ were added to each well of 24 wells and treated with 2, 4, 6 and $8 \mu \mathrm{g} /$ $\mathrm{mL}$ of arsenic trioxide (ATO) for $24 \mathrm{~h}$. Control cells were processed exactly as ATO-treated cells, except ATO treatment of these cells was eliminated. After the incubation period, cellular DNA was extracted from whole cultured cells using genomic DNA isolation reagents from Roche Molecular Biochemicals
(Indianapolis, IN) according to the manufacturer's protocol. Extracted DNA samples were placed into the well of agarose gel. The agarose gels were run at 75 volts until the purple tracer marker migrated to approximately $2 \mathrm{~cm}$ before the end of the gel. After electrophoresis, the gel was stained with ethidium bromide, and photographed under UV light [26].

\section{Data analysis}

Data were presented as means \pm SDs. Statistical analysis was done using one way analysis of variance (ANOVA Dunnett's test) for multiple samples. Student's paired ttest was used to analyze the difference between the control and arsenic trioxide-treated cells. All p-values $<0.05$ were considered to be significant. Tables were constructed to illustrate the dose-response relationship with respect to annevin $\mathrm{V}$ and caspase- 3 positive cells.

\section{Results}

\section{Modulation of phosphatidylserine externalization by arsenic trioxide}

The response of HL-60 promyelocytic leukemia cells exposed to arsenic trioxide (ATO) was assessed by flow cytometry using Annexin V FITC/PI assay kit. As seen in Figure 2, there was a gradual increase in annexin $\mathrm{V}$ positive cells (apoptotic cells) in ATO-treated cells compared to the control. However, a marked and dose-dependent decrease in annexin V-positive cells was detected at $8 \mu \mathrm{g} /$ $\mathrm{ml}$ of ATO, probably due to high level of cell death. The percentages of annexin V-positive cells in ATO-treated HL-60 populations were statistically significantly different compared to the percentages of annexin $\mathrm{V}$ cells in control group populations (Table 1). ATO-treated HL-60 cells were significantly different $(p<0.05)$ compared to the control group according to ANOVA Dunnett's test.

\section{Activation of caspase-3 by arsenic trioxide}

The activity of caspase-3 in HL-60 promyelocytic leukemia cells exposed to arsenic trioxide (ATO) was assessed by flow cytometry. As seen in Figure 3, there was a strong dose-response relationship between caspase- 3 activation in HL-60 cells and ATO exposure. After $24 \mathrm{~h}$ of exposure, the percentages of caspase-3 positive cells (apoptotic cells) were $1.1 \pm 0.3 \%, 17.5 \pm$ $8.9 \%, 27.0 \pm 2.4 \%, 62.5 \pm 8.8 \%$, and $63.1 \pm 9.7 \%$ in 0,2 , 4,6 , and $8 \mu \mathrm{g} / \mathrm{mL}$ of ATO, respectively (Table 2 ). We observed significant differences $(p<0.05)$ between the control and AT-treated cells within the range of 4-8 $\mu \mathrm{g} /$ $\mathrm{mL}$ of ATO.

\section{Induction of nucleosomal DNA fragmentation by arsenic trioxide}

Agarose gel electrophoresis of DNA extracted from control and arsenic trioxide (ATO)-treated cells is presented 

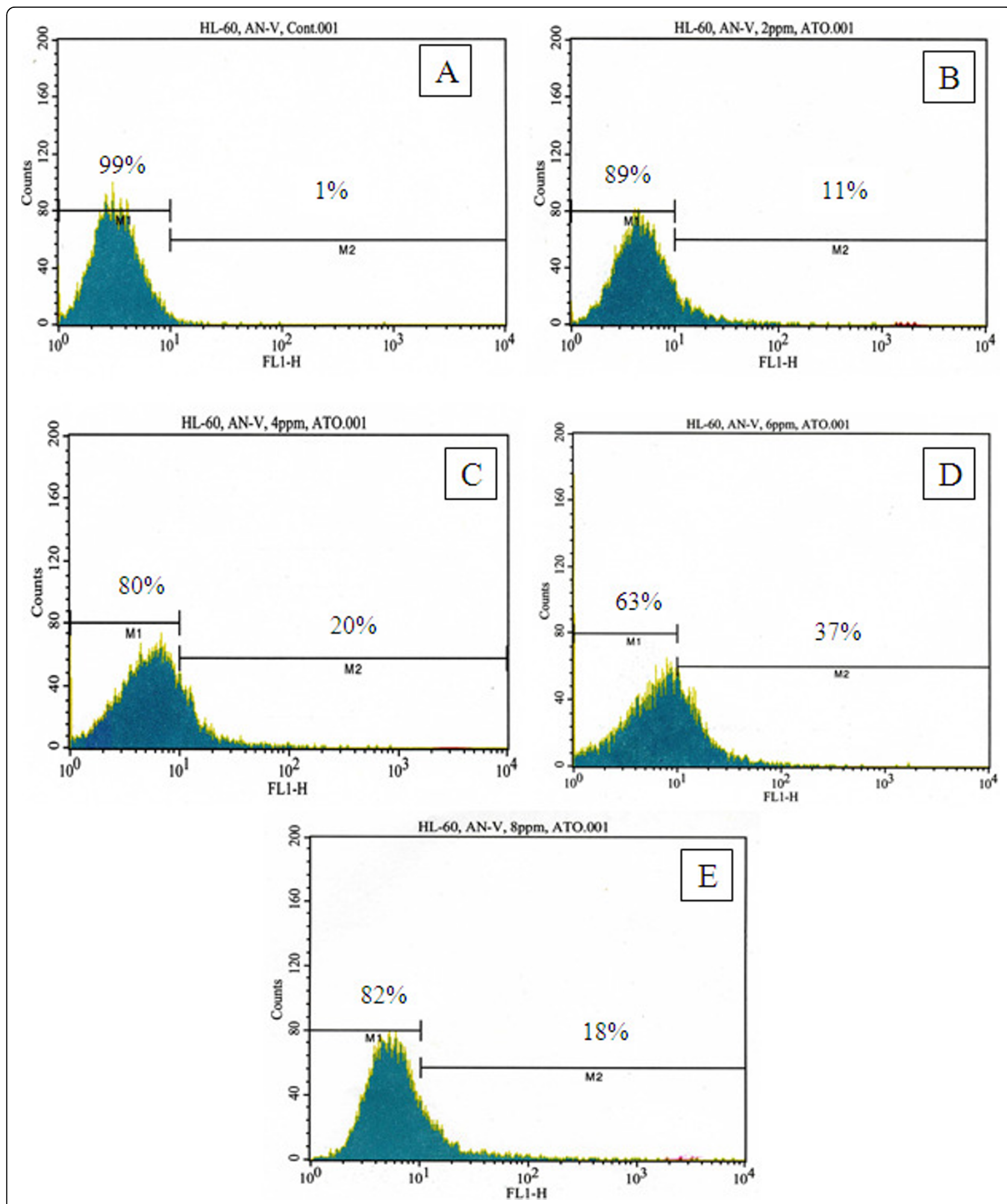

Figure 2 Representative flow cytometry analysis data from Annexin V-FITC/PI assay. The histograms show a comparison of the distribution of annexin $V$ negative cells (M1) and annexin $V$ positive cells (M2) after $24 \mathrm{~h}$ exposure to ATO. A-control; B-2 $\mu \mathrm{g} / \mathrm{mL} ; \mathrm{C}-4 \mu \mathrm{g} / \mathrm{Ml}$; D-6 $\mu \mathrm{g} / \mathrm{mL} ; \mathrm{E}-8 \mu \mathrm{g} / \mathrm{mL}$. 
Table 1 Summary data of annexin $V$ assay obtained from the flow cytometry analysis

\begin{tabular}{ccc}
\hline ATO Concentrations & $\begin{array}{c}\text { Annexin-V Negative Cells or Viable Cells } \\
\text { (Mean } \pm \text { SD)\% }\end{array}$ & $\begin{array}{c}\text { Annexin-V Positive Cells or Apoptotic Cells } \\
\text { (Mean } \pm \text { SD)\% }\end{array}$ \\
\hline $0 \mu \mathrm{g} / \mathrm{mL}$ & $99.0 \pm 0.0$ & $1.0 \pm 0.0$ \\
$2 \mu \mathrm{g} / \mathrm{mL}$ & $88.5 \pm .07$ & $11.5 \pm 0.7$ \\
$4 \mu \mathrm{g} / \mathrm{mL}$ & $80.4 \pm 5.7^{*}$ & $19.6 \pm 5.7^{*}$ \\
$6 \mu \mathrm{g} / \mathrm{mL}$ & $64.2 \pm 5.3^{*}$ & $35.8 \pm 5.3^{*}$ \\
$8 \mu \mathrm{g} / \mathrm{mL}$ & $82.4 \pm 0.5^{*}$ & $17.6 \pm 0.5^{*}$ \\
\hline
\end{tabular}

$\mathrm{HL}-60$ promyelocytic leukemia cells were cultured in the absence or presence of ATO for $24 \mathrm{~h}$ as indicated in the Materials and Methods. Values are shown as means \pm SDs of 3 replicates per experiment. *Significantly different at $p<0.05$ to the control group.

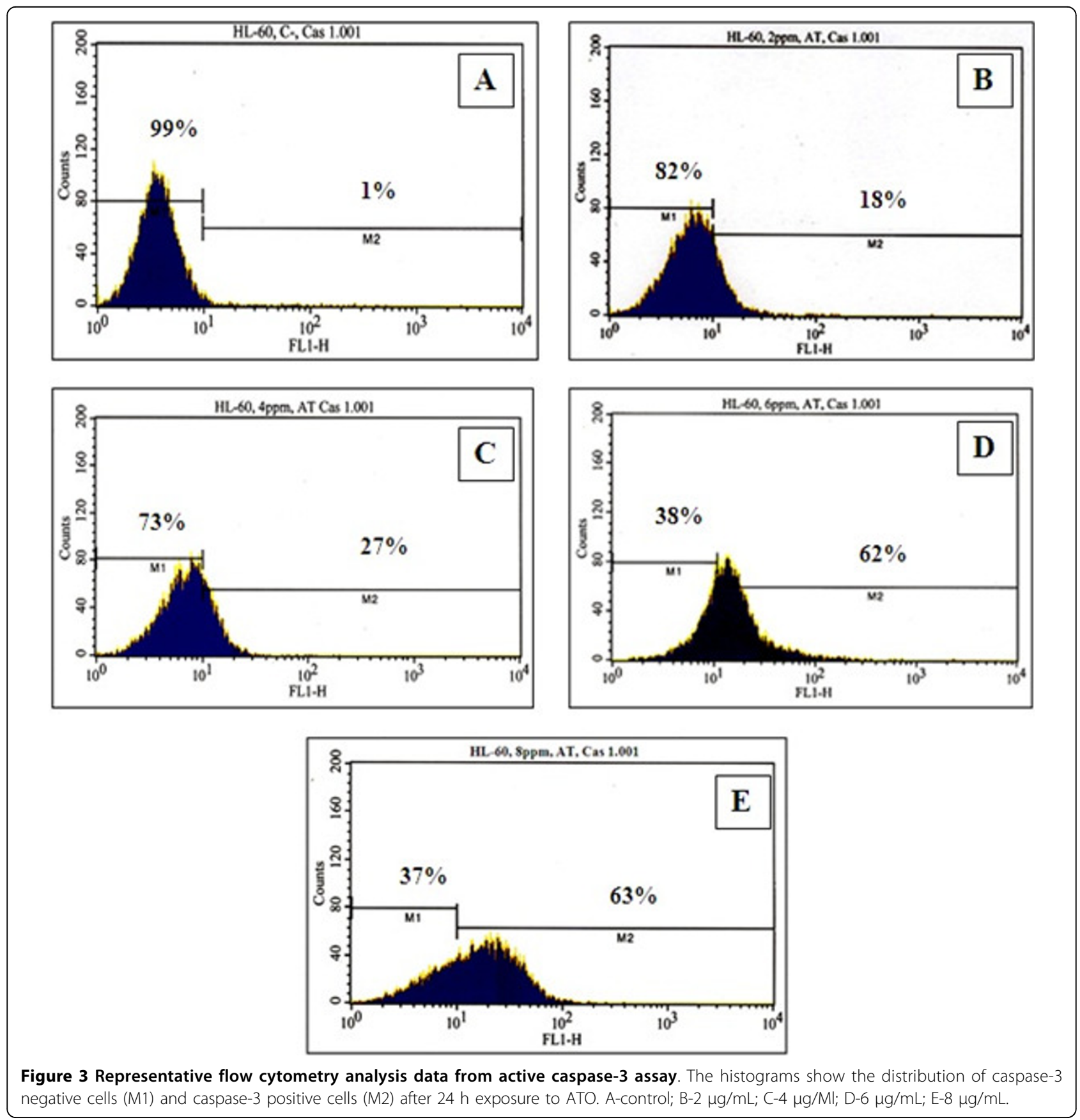


Table 2 Summary data of caspase-3 assay obtained from the flow cytometry analysis

\begin{tabular}{ccc}
\hline ATO Concentrations & $\begin{array}{c}\text { Caspase-3 Negative Cells or Viable Cells } \\
\text { (Mean } \pm \text { SD)\% }\end{array}$ & $\begin{array}{c}\text { Caspase-3 Positive Cells or Apoptotic Cells } \\
\text { (Mean } \pm \text { SD)\% }\end{array}$ \\
\hline $0 \mu \mathrm{g} / \mathrm{mL}$ & $98.7 \pm 0.6$ & $1.1 \pm 0.3$ \\
$2 \mu \mathrm{g} / \mathrm{mL}$ & $82.5 \pm 8.9^{*}$ & $17.5 \pm 8.9^{*}$ \\
$4 \mu \mathrm{g} / \mathrm{mL}$ & $63.0 \pm 2.4^{*}$ & $27.0 \pm 2.4^{*}$ \\
$6 \mu \mathrm{g} / \mathrm{mL}$ & $37.5 \pm 8.8^{*}$ & $62.5 \pm 8.8^{*}$ \\
$8 \mu \mathrm{g} / \mathrm{mL}$ & $36.9 \pm 9.7^{*}$ & $63.1 \pm 9.7^{*}$ \\
\hline
\end{tabular}

HL-60 promyelocytic leukemia cells were cultured in the absence or presence of ATO for $24 \mathrm{~h}$ as indicated in the Materials and Methods. Values are shown as means \pm SDs of 3 replicates per experiment. *Significantly different at $p<0.05$ to the control group.

in (Figure 4). As shown on this figure, our result showed a positive nucleosomal DNA fragmentation in nuclei isolated from HL-60 promyelocytic leukemia cells. A small fragment of DNA double-strand breaks was detected in cells incubated in the absence of ATO. Overall, the present observation demonstrates that ATO exposure induced nucleosomal DNA fragmentation in HL-60 promyelocytic leukemia cells.

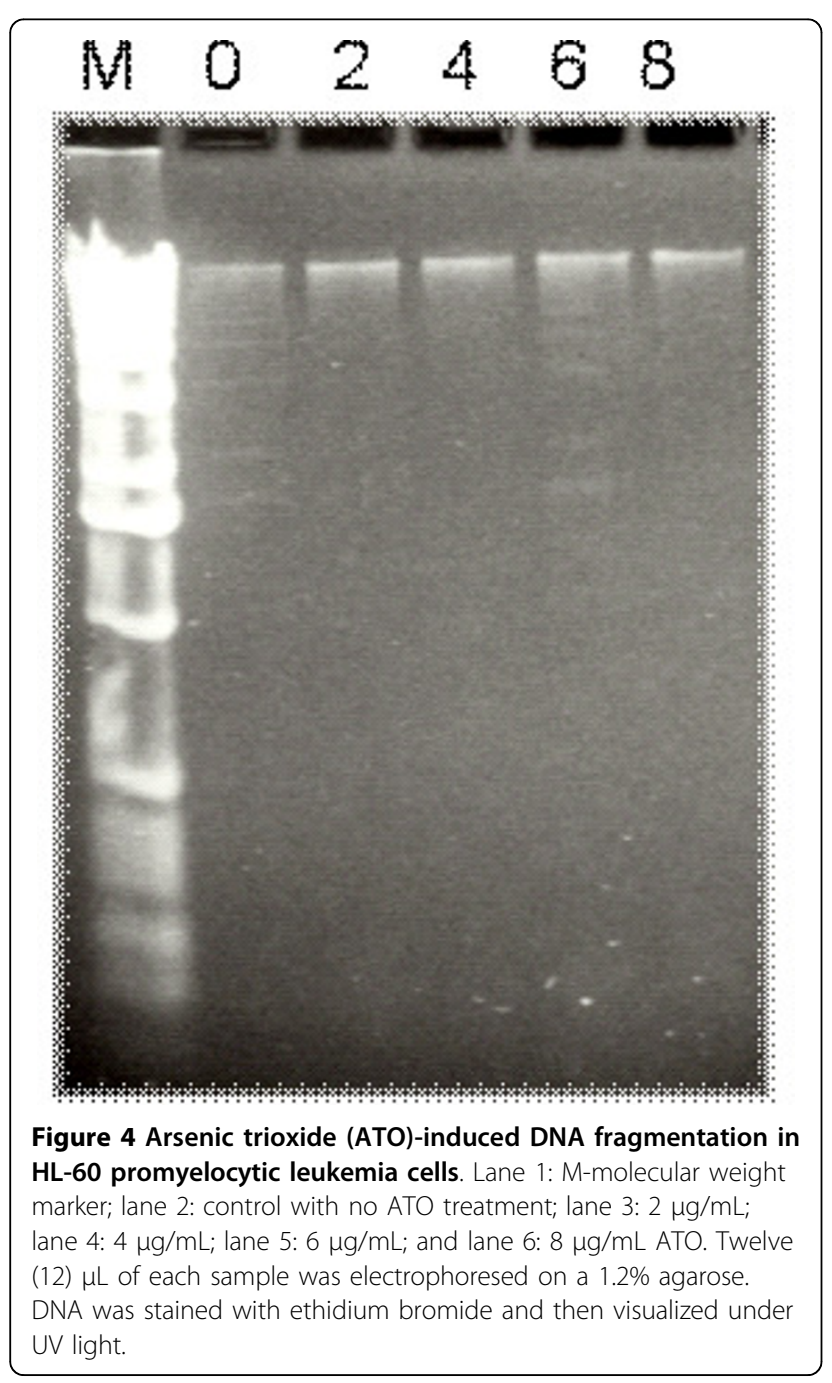

\section{Discission}

Cell death is thought to take place at least by two processes that include apoptosis and necrosis. Apoptosis is an active and physiological mode of cell death. It is generally believed to be mediated by active intrinsic mechanisms, although extrinsic factors can contribute [27-30]. Apoptosis is genetically controlled and is defined by cytoplasmic and nuclear shrinkage, chromatin margination and fragmentation, and breakdown of the cell into multiple spherical bodies that retain membrane integrity [31,32]. In contrast, necrosis is an uncontrolled cell death that is characterized by progressive loss of cytoplasmic membrane integrity, rapid influx of $\mathrm{Na}^{+}, \mathrm{Ca}^{2+}$, and water, resulting in cytoplasmic swelling and nuclear pyknosis [33-35]. The latter feature leads to cellular fragmentation and release of lysosomal and granular contents into the surrounding extracellular space, with subsequent inflammation [30-32].

To gain insight into the mechanism of arsenic trioxide (ATO)-induced apoptosis, we examined the modulation of phosphatidylserine externalization in HL-60 promyelocytic leukemia cells. We observed that ATO induces cellular apoptosis in HL-60 promyelocytic leukemia cells in a dose-dependent manner, showing an increase expression of annexin positive cells in ATO-treated cells compared to the control. Annexin-V is a specific phosphatidylserine-binding protein used to detect apoptotic cells by providing an assessment of the progression from living cells (annexin-/PI-) towards apoptotic stage (annexin+/PI-) and postapoptotic cell death (annexin $+/ \mathrm{PI}+)$. The effect of ATO was more pronounced at 6 $\mu \mathrm{g} / \mathrm{mL}(p<0.05)$ compared to the control cells. We observed that the percentage of annexin positive cells (apoptotic cells) increased gradually $(p<0.05)$ in a dose-dependent manner with increasing ATO concentrations and reached a maximum of $(35.8 \pm 5.3) \%$ cell death after 24.h of exposure. Above $6 \mu \mathrm{g} / \mathrm{mL}$ exposure, ATO failed to further increase apoptosis, probably due to the high level of necrotic cell death at $8 \mu \mathrm{g} / \mathrm{mL}$ of exposure. From a recently published study (Figure 1), we reported that ATO is highly cytotoxic to HL-60 promyelocytic leukemia cells, showing a $24 \mathrm{~h}-\mathrm{LD}_{50}$ of 
$6.4 \pm 0.7 \mu \mathrm{g} / \mathrm{mL}$ [13]. Consistent with our result, previous studies have indicated that low concentrations ATO $(2 \mu \mathrm{M})$ induces apoptosis in HPV 16 DNAimmortalized human cervical epithelial cells and its molecular pathways leading to apoptosis may be associated with down-regulation of viral oncogene expression [36].

To further gain insight into the mechanism of arsenic trioxide (ATO)-induced apoptosis, we examined caspase-3 activation in HL-60 promyelocytic leukemia cells. Caspase-3 is known as a key component of the apoptotic machinery and appears to be the most executant, which can be activated during the early and late stages of apoptosis [37]. It also a protein which has been shown to play a pivotal role in the execution phase of apoptosis induced by diverse stimuli [38]. As shown on Figure 3, we have demonstrated that ATO significantly induces apoptosis of HL-60 cells in a dose-dependent manner, at least in part, through activation of caspase-3. We have found that the percentage of caspase- 3 positive cells (apoptotic cells) increases gradually with increasing ATO concentrations and reached a maximum cell death of $63.1 \pm 9.7 \%$ at $8 \mu \mathrm{g} / \mathrm{mL}$ after $24 . \mathrm{h}$ of exposure. This study suggests that active caspase- 3 plays an important role in executing apoptosis in ATO-treated HL-60 cells. Consistent with our results, ATO-induced apoptosis and related caspase activation have also been studied in HL60 cells although different approaches to detect apoptosis were adopted in that study [39]. Recent studies have reported that low concentrations of ATO, in the range of clinically effective concentrations (1-5 $\mu \mathrm{M})$, induce partial apoptosis of $\mathrm{T}$ lymphocytes by increasing oxidative stress and caspase activation [40]. ATO has also been shown to induce apoptosis in NB4 and mouse $B$ cell leukemia cells [5]. One report has also indicated that arsenic-induced apoptosis in B-cell leukemia cell lines occurred through the involvement of caspases such as caspase 1 and caspase 3, and the down regulation of Bcl-2 [41]. Overall, our results indicate that active caspase-3 is involved in ATO-induced apoptosis in HL-60 cells. However, further investigations are needed to determine whether or not specific activators of caspace3 may be directly associated with the induction of cell death.

To confirm the apoptotic mechanism of arsenic trioxide (ATO) for the above results, we further examined the apoptotic response, as judged by the appearance of a DNA ladder through agarose gel electrophoresis. We observed DNA ladders in extracts from HL-60 cells treated with ATO at concentrations of 2, 4, 6, and $8 \mu \mathrm{g} /$ $\mathrm{mL}$ for $24 \mathrm{~h}$. DNA Laddering is a characteristic pattern of nucleosomal DNA fragmentation, which is the hallmark of apoptosis. DNA fragmentation is one of the later stages of apoptosis [42]. Previous researches have indicated that ATO triggers apoptosis in APL cells by degrading promyelocytic leukemia and retinoic acid

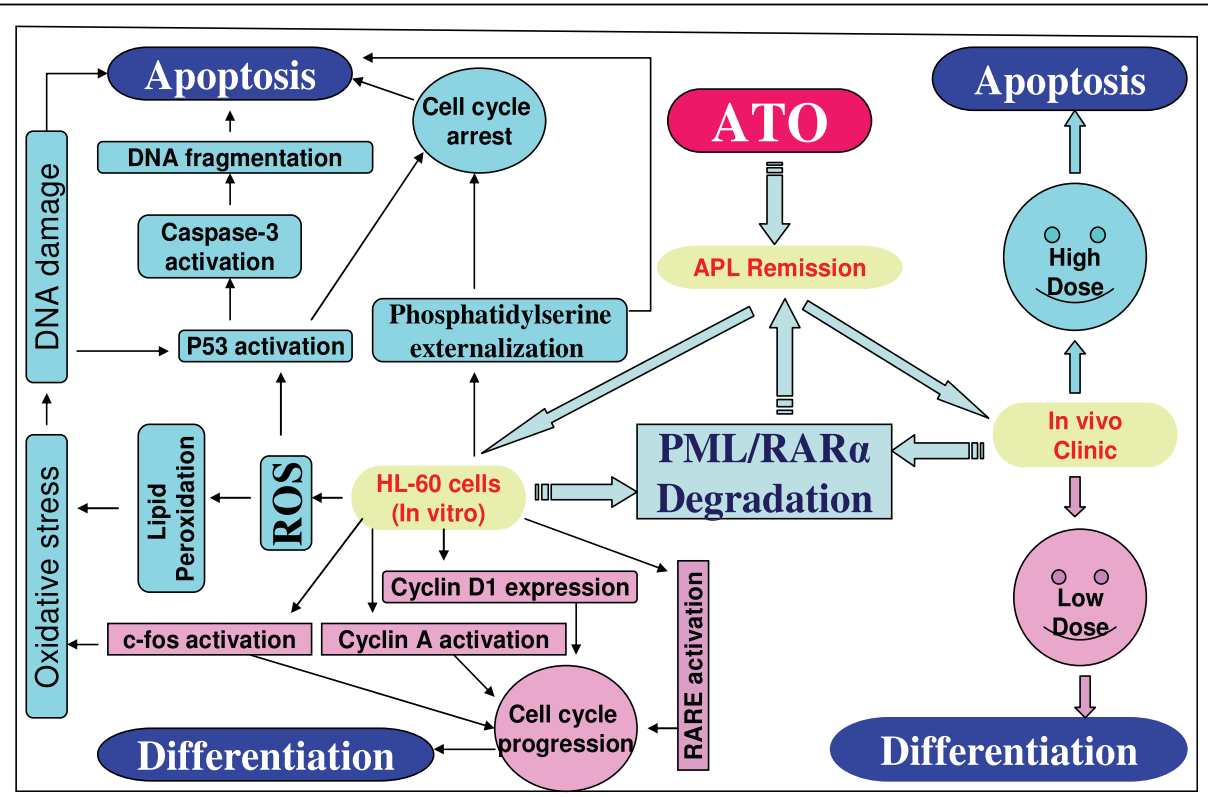

Figure 5 Schematic representation of the apoptotic mechanisms of arsenic trioxide (ATO) as a therapeutic agent in the treatment of acute promyelocytic leukemia. ATO exerts a dual effect on HL-60 cells by inducing partial differentiation and apoptosis. As shown on Figure 5, the mechanisms by which ATO induces apoptosis is mediated through oxidative stress [13] that leads to DNA damage and cell death [44], upregulation of p53 tumor suppressor protein and repression of the c-fos transcription factor [18], induction of phosphatidylserine externalization, caspase-3 activation, and nucleosomal DNA fragmentation. 
receptor-a fusion protein $[5,43]$. In vitro, ATO induces apoptosis in hematological malignancies and several solid tumor cells at lower concentrations $[6,15,44]$, and causes acute necrosis in various cell lines at higher concentrations [6]. As shown in Figure 5, a series of recently published studies in our laboratory have demonstrated that the apoptotic mechanism of ATO as an anti-cancer drug may be associated with DNA damage and cell death [45], up-regulation of p53 tumor suppressor protein and repression of the $c$-fos transcription factor [18] as result of oxidative stress [13]. A recent publication by Platanias has reported that ATOinduced cell death or apoptosis is associated with the depredation of oncoproteins, activation and suppression of pro-apoptotic and anti-apoptotic proteins respectively, generation of reactive oxygen species (ROS) which leads to the decrease in mitochondrial potential and activation of caspases in leukemia cells [46]. Together, data from annexin V assay, caspase-3 assay, and DNA fragmentation analysis collectively show that ATO induces apoptosis in HL-60 promyelocytic leukemia cells. Consistently, a recent report has indicated that ATO activates the intrinsic (mitochondrial) pathway of apoptosis, which involves the disruption of mitochondrial membrane potential, increased $\mathrm{Bax} / \mathrm{Bcl}-2$ ratio and caspase- 9 activation, as well as the extrinsic death receptor pathway mediated by Fas and caspase- 8 activation in acute megakaryocytic leukemia [47]. Our result is in support of previous findings indicating that ATO induces clinical remission in a high proportion of patients with APL by inducing apoptosis [2,9].

\section{Conclusions}

We have demonstrated in the present in vitro study that relevant concentrations of arsenic trioxide (ATO) induce apoptosis of HL-60 promyelocytic leukemia cells. Although the exact mechanisms under which ATO exerts its therapeutic effect in APL cancer are not well elucidated, we have shown in the present study that ATO represents an apoptosis-inducing agent in HL-60 promyelocytic leukemia cells. Its apoptotic mechanisms involve the induction of phosphatidylserine externalization, caspase- 3 activation, and nucleosomal DNA fragmentation.

\footnotetext{
Acknowledgements

The research described in this publication was made possible by a grant from the National Institutes of Health (Grant No. 5G12RR013459-12), through the RCMI-Center for Environmental Health at Jackson State University. An oral presentation on this manuscript was presented at the 7th International Drug Discovery Science and Technology Conference at Shanghai, China in October 22-26, 2009
}

\footnotetext{
Author details

${ }^{1}$ Cellomics and Toxicogenomics Research Laboratory, NIH-RCMI Center for Environmental Health, College of Science, Engineering and Technology,
}

Jackson State University, 1400 Lynch Street, Box 18540, Jackson, Mississippi, USA. ${ }^{2}$ Department of Medicine, Division of Rheumatology and Immunology, University of Mississippi Medical Center, 2500 North State Street, Jackson, Mississippi, 39216, USA.

\section{Authors' contributions}

CY and PT conceived, designed and implemented the study, and drafted the manuscript.

$\mathrm{JJ}$ and RM participated in the implementation of the study, and the acquisition, analysis and interpretation of data. All authors read and approved the final draft of the manuscript.

\section{Competing interests}

The authors declare that they have no competing interests.

Received: 24 June 2010 Accepted: 26 August 2010

Published: 26 August 2010

\section{References}

1. Haller JS: Therapeutic mule: the use of arsenic in the nineteenth century material medica. Pharmacy in History 1975, 17:87-100.

2. Shen ZX, Chen GQ, Ni JH, Li XS, Xiong SM, Qiu QY, Zhu J, Tang W, Sun GL, Yang KQ, Chen Y, Zhou L, Fang ZW, Wang YT, Ma J, Zhang P, Zhang TD, Chen SJ, Chen Z, Wang ZY: Use of arsenic trioxide in the treatment of acute promyelocytic leukemia (APL): II. Clinical efficacy and pharmacokinetics in relapsed patients. Blood 1997, 89:3354-3360.

3. Sun HD, Ma L, Hu XC: Ai-Lin 1 treated 32 cases of acute promyelocytic leukemia. Chin J Integr Chin West Med 1992, 12:170-172.

4. Zhang P, Wang SY, Hu XH: Arsenic trioxide treated 72 cases of acute promyelocytic leukemia. Chin J Hematol 1996, 17:58-62.

5. Chen GQ, Zhu J, Shi XG, Ni JN, Zhong HJ, Si GY, Jin XL, Tang W, Li XS, Xong SM, Shen ZX, Sun GL, Ma J, Zhang P, Zhang TD, Gazin C, Naoe T, Chen SJ, Wang ZY, Chen Z: In vitro studies on cellular and molecular mechanisms of arsenic trioxide (As2O3) in the treatment of acute promyelocytic leukemia: As2O3 induces NB4 cell apoptosis with downregulation of $\mathrm{BCl}-2$ expression and modulation of PML-RAR/PML proteins. Blood 1996, 88:1052-1061.

6. Rousselot P, Labaume S, Marolleau JP, Larghero J, Noguera MH, Brouet JC, Fermand JP: Arsenic trioxide and melarsoprol induce apoptosis in plasma cell lines and in plasma cells from myeloma patients. Cancer Res 1999, 59:1041-1048.

7. Shen L, Chen TX, Wang YP, Lin Z, Zhao HJ, Zu YZ, Wu G, Ying DM: Arsenic trioxide induced apoptosis of the human $B$ lymphoma cell line MBC-1. J Biol Regulat Homeost Agent 2000, 14:116-119.

8. Wang ZG, Rivi R, Delva L, Konig A, Scheinberg DA, Gambacorti-Passerini C, Gabrilove JL, Warrell RP Jr, Pandolfi PP: Arsenic trioxide and melarsoprol induce programmed cell death in myeloid leukemia cell lines and function in a PML and PML/RAR- independent manner. Blood 1998, 92:1497-1504.

9. Soignet SL, Maslak P, Wang ZG, Jhanwar S, Calleja E, Dardashti LJ, Corso D, DeBlasio A, Gabrilove J, Scheinberg DA, Pandolfi PP, Warrell RP: Complete remission after treatment of acute promyelocytic leukemia with arsenic trioxide. N Engl J Med 1998, 339:1341-1348.

10. Chen YC, Lin-Shiau SY, Lin JK: Involvement of reactive oxygen species and caspase 3 activation in arsenite-induced apoptosis. J Cell Physiol 1998, 177:324-333

11. Jing Y, Dai J, Chalmers-Redman RM, Tatton WG, Waxman S: Arsenic trioxide selectively induces acute promyelocytic leukemia cell apoptosis via a hydrogen peroxide-dependent pathway. Blood 1999, 94:2102-2111.

12. Huang HS, Chang WC, Chen CJ: Involvement of reactive oxygen species in arsenite-induced downregulation of phospholipid hydroperoxide glutathione peroxidase in human epidermoid carcinoma A431 cells. Free Radic Biol Med 2002, 33:864-873.

13. Yedjou CG, Tchounwou PB: Oxidative stress in human leukemia (HL-60), human liver carcinoma $\left(\mathrm{HepG}_{2}\right)$, and human Jurkat-T cells exposed to arsenic trioxide. Metal lons Biol Med 2006, 9:293-297.

14. Bazarbachi A, El-Sabban ME, Nasr R, Quignon F, Awaraji C, Kersual J, Dianoux L, Zermati Y, Haidar JH, Hermine O, de Thé H: Arsenic trioxide and interferon- synergize to induce cell cycle arrest and apoptosis in human T-cell lymphotropic virus type I-transformed cells. Blood 1999, 93:278-273. 
15. Zhu $X H$, Shen $Y L$, Jing $Y K$, Cai $X$, Jia $P M$, Huang $Y$, Tang $W$, Shi GY, Sun $Y P$, Dai J, Wang ZY, Chen SJ, Zhang TD, Waxman S, Chen Z, Chen GQ: Apoptosis and growth inhibition in malignant lymphocytes after treatment with arsenic trioxide at clinically achievable concentrations. $J$ Natl Cancer Inst 1999, 91:772-778.

16. Akao $Y$, Nakagawa $Y$, Akiyama $K$ : Arsenic trioxide induces apoptosis in neuroblastoma cell lines through the activation of caspase 3 in vitro. FEBS Lett 1999, 455:59-62.

17. Thomas $D$, Tyers M: Transcriptional regulation: kamikaze activators. Curr Biol 2000, 10:341-343.

18. Yedjou CG, Tchounwou PB: Arsenic trioxide-induced modulation of p53, c-fos, RARE, cyclin D1, and cyclin A in human leukemia (HL-60) cells. Mol Cell Biochem 2009, 331(1-2):207-214.

19. Yedjou CG, Rogers C, Brown E, Tchounwou PB: Differential effect of ascorbic acid and n-acetyl-I-cysteine on arsenic trioxide-mediated oxidative stress in human leukemia (HL-60) cells. J Biochem Mol Toxicol 2008, 22(2):85-92.

20. Yedjou CG, Thuisseu LD, Tchounwou CK, Gomes M, Howard C, Tchounwou PB: Ascorbic acid potentiation of arsenic trioxide anticancer activity against acute promyelocytic leukemia. Archives of Drug Information 2009, 2(4):59-65.

21. Park WH, Seol JG, Kim ES, Hyun JM, Jung CW, Lee CC, Kim BK, Lee YY: Arsenic trioxide-mediated growth inhibition in MC/CAR myeloma cells via cell cycle arrest in association with induction of cyclin-dependent kinase inhibitor, p21, and apoptosis. Cancer Res 2000, 60:3065-3071.

22. Yedjou CG, Moore P, Tchounwou PB: Dose and time-dependent response of human acute promyelocytic leukemia (HL-60) cells to arsenic trioxide treatment. Int J Environ Res Public Health 2006, 2:136-140.

23. Koopman $G$, Reutelingsperger CP, Kuijten GA, Keehnen RM, Pals ST, Van Oers $\mathrm{MH}$ : Annexin $\mathrm{V}$ for flow cytometric detection of phosphatidylserine expression on B cells undergoing apoptosis. Blood 1994, 84(5):1415-1420.

24. Vermes I, Haanen C, Steffens-Nakken H, Reutelingsperger C: A novel assay for apoptosis. Flow cytometric detection of phosphatidylserine expression on early apoptotic cells using fluorescein labelled Annexin V. $\mathrm{J}$ Immunol Methods 1995, 184(1):39-51.

25. Belloc F, Belaud-Rotureau MA, Lavignolle V, Bascans E, Braz-Pereira E, Durrieu F, Lacombe F: Flow cytometry detection of caspase 3 activation in preapoptotic leukemic cells. Cytometry 2000, 40:151.

26. Yeung MC: Accelerated apoptotic DNA laddering protocol. Biotechniques 2002, 33(4):734-736.

27. Bellamy CO, Malcomson RD, Harrison DJ, Wyllie AH: Cell death in health and disease: the biology and regulation of apoptosis. Semin Cancer Biol 1995, 6:3-16.

28. Chalmers-Redman RM, Fraser AD, Ju WY, Wadia J, Tatton NA, Tatton WG: Mechanisms of nerve cell death: apoptosis or necrosis after cerebral ischemia. Int Rev Neurobiol 1997, 40:1-25.

29. Johnstone RJ, Ruefli AA, Lowe SW: Apoptosis: a link between cancer genetics and chemotherapy. Cell 2002, 108:153-164.

30. Padanilam BJ: Cell death induced by acute renal injury: a perspective on the contributions of apoptosis and necrosis. Am J Physiol Renal Physiol 2003, 284:F608-F627

31. Buja LM, Eigenbrodt ML, Eigenbrodt EH: Apoptosis and necrosis. Basic types and mechanisms of cell death. Arch Pathol Lab Med 1993, 117:1208-1214.

32. Majno G, Joris I: Apoptosis, oncosis, and necrosis: an overview of cell death. Am J Pathol 1995, 146:3-15.

33. Wyllie $A H$ : Death from inside out: an overview. Philos Trans $R$ Soc Lond $B$ Biol Sci 1994, 345:237-241.

34. Berridge MJ, Lipp P, Bootman MD: The versatility and universality of calcium signaling. Nat Rev Mol Cell Biol 2000, 1:11-21.

35. Barros LF, Hermosilla T, Castro J: Necrotic volume increase and the early physiology of necrosis. Comp Biochem Physiol A 2001, 130:401-409.

36. Zheng J, Deng YP, Lin C, Fu M, Xiao PG, Wu M: Arsenic trioxide induces apoptosis of HPV16 DNA-immortalized human cervical epithelial cells and selectively inhibits viral gene expression. Int J Cancer 1999, 82(2):286-92.

37. Patel T, Gores GJ, Kaufmann SH: The role of proteases during apoptosis. FASEB J 1996, 10:587-597.

38. Platanias LC: Biological responses to arsenic compounds. J Biol Chem 2009, 284(28):18583-18587.
39. Lockshin RA, Zakeri Z: Caspase-independent cell deaths. Curr Opin Cell Biol 2002, 14:727-33.

40. Gupta S, Yel L, Kim D, Kim C, Chiplunkar S, Gollapudi S: Arsenic trioxide induces apoptosis in peripheral blood T lymphocyte subsets by inducing oxidative stress: a role of Bcl-2. Mol Cancer Ther 2003, 2:711-719.

41. Akao Y, Mizoguchi H, Kojima S, Naoe T, Ohishi N, Yagi K: Arsenic induces apoptosis in B-cell leukaemic cell lines in vitro: activation of caspases and down-regulation of Bcl-2 protein. Br J Haematol 1998, 102:1055-1060.

42. Saraste A, Pulkki K: Morphologic and biochemical hallmarks of apoptosis. Cardiovasc Res 2000, 45:528-537.

43. Shao W, Fanelli M, Ferrara FF, Riccioni R, Rosenauer A, Davison K, Lamph WW, Waxman S, Pelicci PG, Lo Coco F, Avvisati G, Testa U, Peschle C, Gambacorti-Passerini C, Nervi C, Miller WH Jr: Arsenic trioxide as an inducer of apoptosis and loss of PML/RAR a protein in acute promyelocytic leukemia cells. J Natl Cancer Inst 1998, 90:124-133.

44. Li YM, Broome JD: Arsenic targets tubulins to induce apoptosis in myeloid leukemia cells. Cancer Res 1999, 59:776-780.

45. Yedjou CG, Tchounwou PB: In vitro cytotoxic and genotoxic effects of arsenic trioxide on human leukemia (HL-60) cells using the MTT and alkaline single cell gel electrophoreis (comet) assays. Mol Cell Biochem 2007, 301:123-130

46. Canestraro M, Galimberti S, Savli H: Synergistic antiproliferative effect of arsenic trioxide combined with bortezomib in HL60 cell line and primary blasts from patients affected by myeloproliferative disorders. Cancer Genet Cytogenet 2010, 199(2):110-120.

47. Lam HK, Li K, Chik KW, Yang M, Liu VC, Li CK, Fok TF, Ng PC, Shing MM, Chuen CK, Yuen PM: Arsenic trioxide mediates intrinsic and extrinsic pathways of apoptosis and cell cycle arrest in acute megakaryocytic leukemia. Int J Oncol 2005, 27(2):537-545.

doi:10.1186/1756-8722-3-28

Cite this article as: Yedjou et al:: Basic Mechanisms of Arsenic Trioxide (ATO)-Induced Apoptosis in Human Leukemia (HL-60) Cells. Journal of Hematology \& Oncology 2010 3:28.

\section{Submit your next manuscript to BioMed Central and take full advantage of:}

- Convenient online submission

- Thorough peer review

- No space constraints or color figure charges

- Immediate publication on acceptance

- Inclusion in PubMed, CAS, Scopus and Google Scholar

- Research which is freely available for redistribution

Submit your manuscript at www.biomedcentral.com/submit
C) Biomed Central 